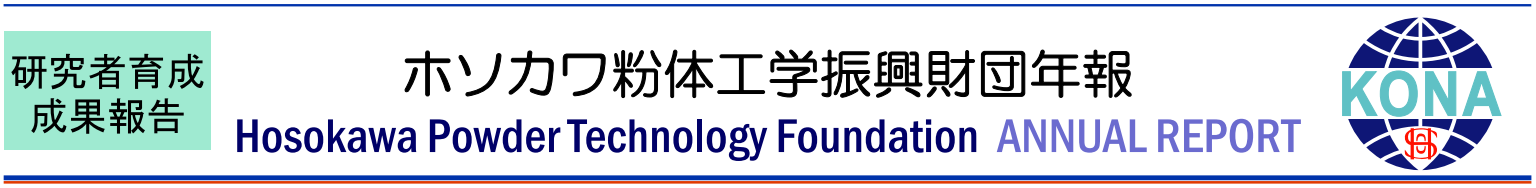

14506

\title{
高濃度固気二相流中での粗大物体の挙動予測モデル開発 \\ A Numerical Model for the Motion of Large Objects in Dense Gas-Solid Two-Phase Flows
}

\author{
援助対象者 Scholarship Student: 東田 恭平 Kyohei HIGASHIDA \\ 大阪大学大学院工学研究科 博士課程後期 2 年 \\ Graduate School of Engineering, Osaka University, PhD Student (D2) \\ E-mail: higashida@cf.mech.eng.osaka-u.ac.jp
}

研究指導者 Academic Leader: 田中 敏嗣 Toshitsugu TANAKA

教授, Professor

E-mail: Tanaka@mech.eng.osaka-u.ac.jp

\section{成 果 の 概 要}

\section{1. 緒言}

固体粒子を含む固気二相流は, 自然界, 工業 装置内において広く観察される。その中でも， 粉粒体を気流で流動化させる気系流動層は, 固 気二相流の典型的例であり, 反応, 燃焼, 乾燥, 造粒, 分離などのプロセスに広く用いられて いる.

流動層の多くの応用において, 層内の固体粒 子サイズは均一ではなく，流動媒体に比べて非 常に大きな粗大物体が混在する。このような層 内における固体サイズの大きな違いは，物体の 偏析といった特徴的な現象を生じさせることが 知られている。したがって, 流動層中の粗大物 体の挙動を予測することは重要であるが, 流動 層中を 3 次元的に動き回る粗大物体を，実験的 に観測するのは難しく, 未だその挙動は十分に 理解されていない.

流動層中の粗大物体運動を数值計算によって 予測する試みとして, Tsuji らは, 流動層内流
れの数值解析に広く用いられている, DEMCFD カップリングモデル（Tsuji Y. et al., 1993） をベースとした計算モデルを開発した（Tsuji T. et al., 2014)．Tsuji らは，計算モデルの検証と して, 十分に流動化させた後に, 気体流入を停 止させ，その後の粗大物体の高さを実験と比較 する方法を採用し，実験と概ね一致することを 確認した（Tsuji T. et al., 2014）。しかし，流動 化中の粗大物体の位置や，粗大物体に作用する 力についての定量的な評価は, 十分にはなされ ておらず，更なる検証が必要である。

そこで本研究では, 流動層中の単一球形粗大 物体に働く力に着目し, 数值計算および実験で 得られた結果を直接比較した。なお本研究で は, 粗大物体の浮沈挙動に大きく関わる鉛直方 向成分の力についてのみ着目した。実験におけ る力の計測は, Haradaらによって開発された, Lagrangian センサーシステム (Harada S. et al., 2011）を用いて行った。 この計測システムは, 自由に運動する物体に作用する力を, 非接触で 計測することが可能である。 


\section{2. 計算モデル}

従来の DEM-CFD カップリングモデルでは, 流体計算に用いるセルのサイズを, 粒子サイズ よりも大きく設定し，また同時に，層内に発生 する気泡のようなメゾスケール構造のサイズよ りも小さく設定する必要がある。そのため, 従 来の DEM-CFD カップリングモデルにおいて, 計算セルサイズよりも大きな物体を直接扱うこ とは不可能である。 そこでTsuji らは，このよ うな計算セルサイズよりも大きな物体を, DEM-CFD カップリングモデルの枠組み内で扱 う手法として, Fictitious Particle Methodを開発 した（Tsuji T. et al., 2014）。この手法では, 直 接数值計算の一種である, Volume penalization 法（Schneider K., 2005）の考えをもとに, 物体 を小さな仮想粒子の充填体とモデル化すること で, 物体一流体間の相互作用を表現している.

流体計算の基礎式は, 次に示す局所相平均量 に対する連続の式と運動方程式である (Anderson TB. and Jackson R., 1967).

$$
\begin{aligned}
& \frac{\partial}{\partial t} \varepsilon+\nabla \cdot(\varepsilon \boldsymbol{u})=0 \\
& \frac{\partial}{\partial t}(\varepsilon \boldsymbol{u})+\nabla \cdot(\varepsilon \boldsymbol{u} \boldsymbol{u})=-\frac{\varepsilon}{\rho_{\mathrm{f}}} \nabla p+\boldsymbol{f}
\end{aligned}
$$

ここで, $\boldsymbol{u}, p, \rho_{\mathrm{f}}, \varepsilon$ はそれぞれ, 局所相平 均された流体速度, 圧力, 流体の密度, 空隙率 である、また， $\boldsymbol{f}$ は，固体－流体間の運動量交 換を表す項である. $\boldsymbol{f}$ の与え方については, Tsuji らによって詳しく説明されている（Tsuji T. et al., 2014).

固体運動は, 個々の粒子および粗大物体につ いての並進と回転の運動方程式を解くことに よって計算される。 また, 固体間の接触力は, ばね, ダッシュポットおよび摩擦スライダー で構成された DEMの接触力モデルを用いて与 えた。

\section{3. 実験手法}

実験における，粗大物体に働く力の計測は, Harada らによって開発された Lagrangian セン サーシステム（Harada S. et al., 2011）を用いて 行った。本センサーシステムは, 3 軸加速度セ ンサー, 3 軸磁気センサーおよび無線モジュー ルで構成されており, これらが球形の殼の内部 に固定されている，センサーからの信号は，無 線でPCに送られる。

図 1 に粗大物体とセンサーから出力されるべ クトルとの関係を示す. 加速度センサーからの 出力 $\tilde{\boldsymbol{a}}$ は, 流体力や接触力による動的な加速度 $\boldsymbol{a}$ に加えて, 重力加速度 $\boldsymbol{g}$ も含まれているため, 重力加速度成分のみを取り除く必要がある。し かし，任意の姿勢をとる粗大物体において，加 速度センサーの出力から, 重力加速度成分のみ を除去するのは難しい. そこで, Harada らは, 重力と同じ方向の外部磁場を与えることで, こ れを解決した (Harada S. et al., 2011).この外 部磁場は, 磁気センサーによって検出され, そ の出力 $\tilde{\boldsymbol{b}}$ 用いることで, 重力加速度は次式に より求められる.

$$
\boldsymbol{g}=|\boldsymbol{g}| \frac{\tilde{\boldsymbol{b}}}{|\tilde{b}|}
$$

式 (3) を用いることで, 動的加速度 $\boldsymbol{a}$ は, 次 式のように求められる.

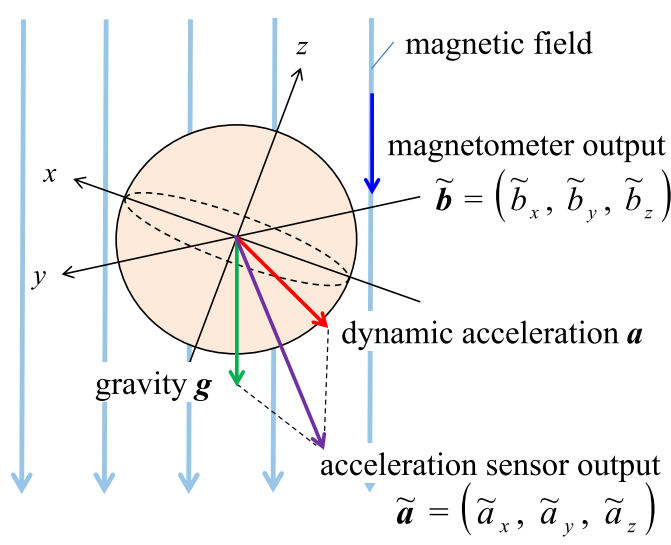

Fig. 1 Output of sensor located in magnetic field 


$$
\boldsymbol{a}=\tilde{\boldsymbol{a}}-|\boldsymbol{g}| \frac{\tilde{\boldsymbol{b}}}{\tilde{\boldsymbol{b}} \mid}
$$

式 (4) で得られる動的加速度 $\boldsymbol{a}$ に, 粗大物体 の質量を掛けることで, 粗大物体に働く力を求 めることができる.

\section{4. 実験および計算条件}

流動層は, 奥行き $150 \mathrm{~mm}$, 幅 $150 \mathrm{~mm}$ の矩 形流動層である。流動媒体として使用する粒子 は, 直径 $2.3 \mathrm{~mm}$, 密度 $2443 \mathrm{~kg} / \mathrm{m}^{3}$ のガラスビー ズであり，初期層高を $150 \mathrm{~mm}$ に設定した。粗 大物体は直径 $30 \mathrm{~mm}$ の球であり, 密度は $990.3 \mathrm{~kg} / \mathrm{m}^{3}$ である。このとき, 静止状態の粒 子層のかさ密度は $1471 \mathrm{~kg} / \mathrm{m}^{3}$ であり, 粗大物 体と粒子層との密度比は 0.67 となる。また, 作動流体には空気を用い，空塔速度 $1.4 \mathrm{~m} / \mathrm{s}$ で

Table 1 Calculation conditions

\begin{tabular}{lc}
\hline Particle and large object & \\
Particle diameter: $d_{\mathrm{p}}[\mathrm{mm}]$ & 2.3 \\
Number of particles: $N_{\mathrm{p}}[-]$ & 326577 \\
Density of particles: $\rho_{\mathrm{p}}\left[\mathrm{kg} / \mathrm{m}^{3}\right]$ & 2443 \\
Bulk density of particle bed: $\rho_{\mathrm{b}}\left[\mathrm{kg} / \mathrm{m}^{3}\right]$ & 1471 \\
Initial bed height: $H_{\mathrm{i}}[\mathrm{mm}]$ & 150 \\
Diameter of large object: $d_{\mathrm{s}}[\mathrm{mm}]$ & 30 \\
Density of large object: $\rho_{\mathrm{s}}\left[\mathrm{kg} / \mathrm{m}^{3}\right]$ & 990.3 \\
$\rho_{\mathrm{s}} / \rho_{\mathrm{b}}[-]$ & 0.67 \\
Gas & \\
Superficial velocity: $u_{0}[\mathrm{~m} / \mathrm{s}]$ & 1.4 \\
Viscosity: $\mu_{\mathrm{f}}[\mathrm{Pa} \mathrm{s}]$ & $1.81 \times 10^{-5}$ \\
Density: $\rho_{\mathrm{f}}\left[\mathrm{kg} / \mathrm{m}^{3}\right]$ & 1.205 \\
Calculation & \\
Time increment: $\Delta t[\mathrm{~s}]$ & \\
Calculation domain & $5.0 \times 10^{-5}$ \\
Depth: $L_{x}[\mathrm{~mm}]$ & \\
Width: $L_{y}[\mathrm{~mm}]$ & \\
Cell size: $\Delta x[\mathrm{~mm}]$ & 500 \\
\hline & \\
\hline
\end{tabular}

流動層下部から一様に流入させた. 本研究では, 重力加速度検出用の外部磁場は, 磁石板を流動 層の上下に設置することで与えた。

計算条件については表 1 に示す。実験，計 算ともに, 粗大物体の初期位置は層表面中央 である。

\section{5. 粗大物体に作用する力とその運動}

図 2，3に，実験および計算における，粗大 物体の運動の様子をそれぞれ示す。今回の条件 では, 粗大物体と粒子層との密度比は 0.67 で

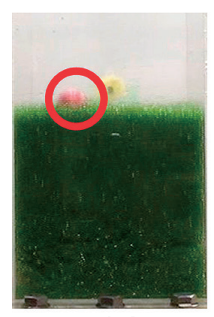

$t=0.2 \mathrm{~s}$

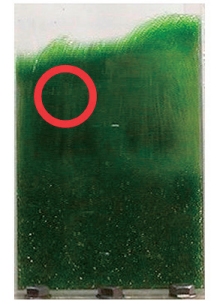

$t=0.5 \mathrm{~s}$

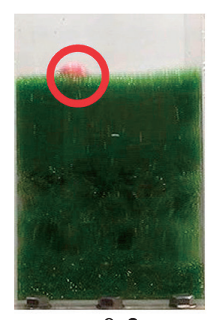

$t=0.3 \mathrm{~s}$

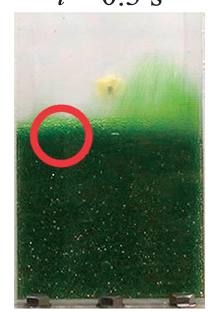

$t=0.6 \mathrm{~s}$

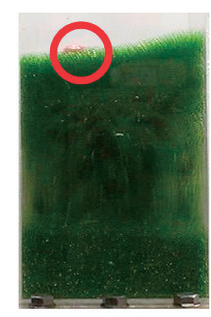

$t=0.4 \mathrm{~s}$

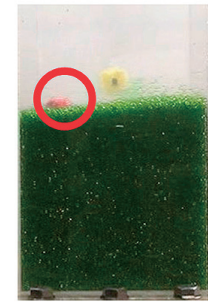

$t=0.7 \mathrm{~s}$
Fig. 2 Snapshot of large object and particles (experiment)
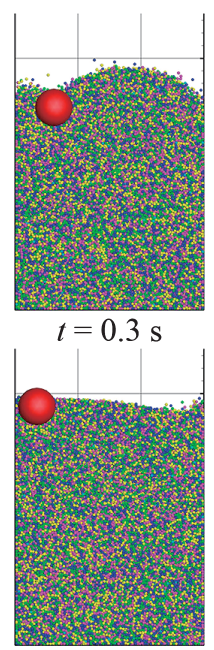

$t=0.6 \mathrm{~s}$

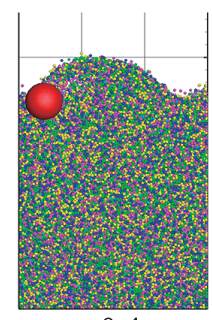

$t=0.4 \mathrm{~s}$

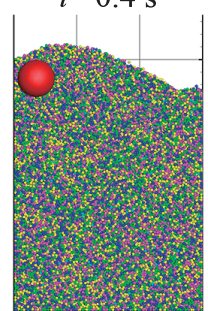

$t=0.7 \mathrm{~s}$

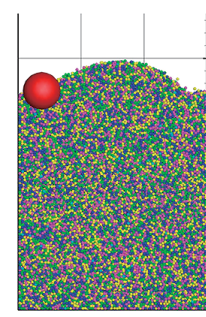

$t=0.5 \mathrm{~s}$

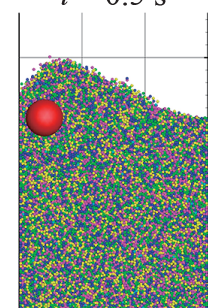

$t=0.8 \mathrm{~s}$
Fig. 3 Snapshot of large object and particles (simulation) 


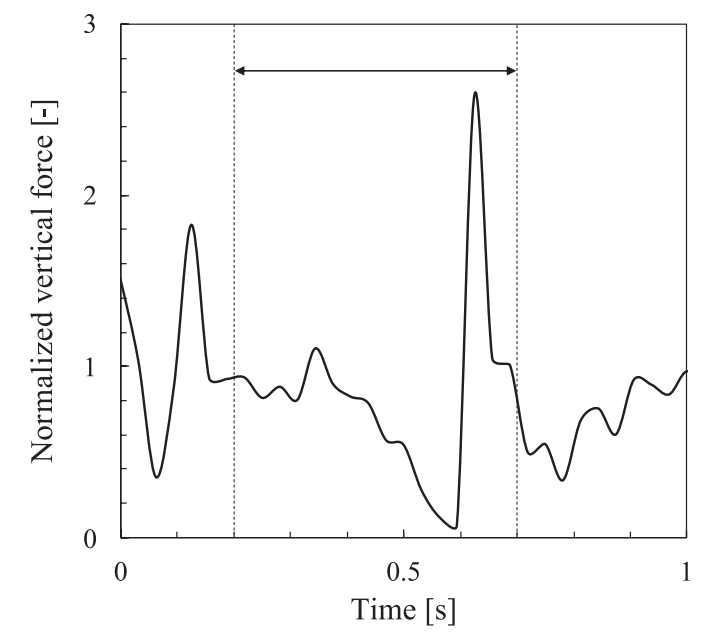

Fig. 4 Vertical force acting on large object (experiment)

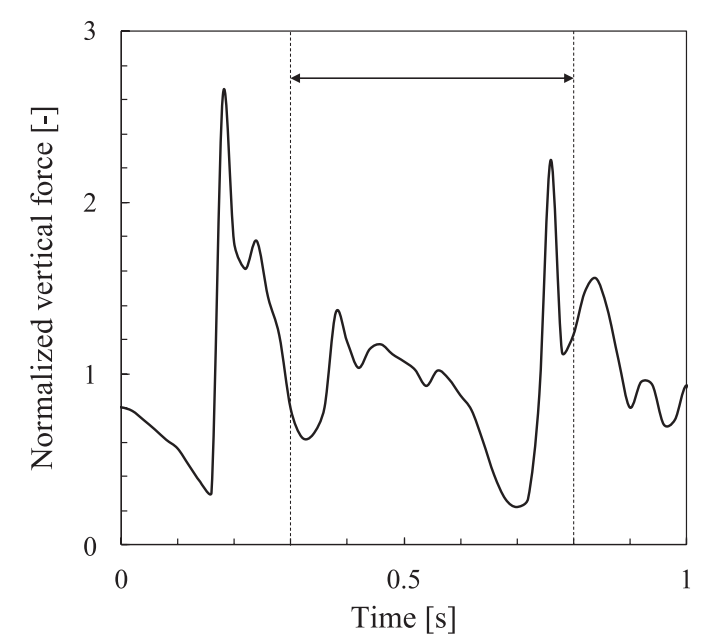

Fig. 5 Vertical force acting on large object (simulation)

あることから, 粗大物体は層内部に貫入するす ることなく, 層表面付近で上下運動している様 子が観察された。図 4,5 に, 実験および計算 で得られた, 粗大物体に働く鉛直方向の力をそ れぞれ示す。この力は，重力成分を取り除いた 動的な力のみを示している. なお，力について は，鉛直上向きを正としており，粗大物体に働 く重力で正規化している. 図2, 3 に示されて いる画像は, 図 4, 5 中に描かれている矢印の
区間にそれぞれ相当する。間の最初は，上向 きの力によって粗大物体は上昇し, その後上向 きの力が減少すると落下する. 落下した粗大物 体は, 粒子層上面に接触し, その時に, 大きな 上向きの力が瞬間的に生じる.これら一連の粗 大物体の運動と, それに対応する力の変化の様 子が, 実験と計算で良く一致していることが確 認された。 また，力のピーク值や，ピークの間 隔などの特徵も，実験と計算で概ね一致してい ることが分かる.

\section{6. 結言}

流動層内の粗大物体に働く鉛直方向の力につ いて, 数值解析結果と, Lagrangian センサーに よる計測結果を直接比較した。その結果, 両者 で良好な一致が確認された。

本稿では, 粗大物体が粒子層内部に貫入する ことがなく, 層表面付近を浮遊している条件で の比較であったため, 今後は層内部を自由運動 する条件での比較を行う予定である。

\section{参考文献}

[1] Anderson TB., Jackson R., A fluid mechanical description of fluidized beds, Industrial \& Engineering Chemistry Fundamentals, 6 (1967) 527-539.

[2] Harada S., Kobayashi Y., Sawano T., Noguchi E., Direct measurement of fluid force on a particle in liquid by telemetry system, International Journal of Multiphase Flow, 37 (2011) 898-905.

[3] Schneider K., Numerical simulation of the transient flow behaviour in chemical reactors using a penalization method, Computers \& Fluid 34 (2005) 1223-1238.

[4] Tsuji T., Higashida K., Okuyama Y., Tanaka T., Fictitious particle method: a numerical model for flows including dense solid s with large size difference, AIChE Journal, 60 (2014) 1606-1620.

[5] Tsuji Y., Kawaguchi T., Tanaka T., Discrete particle simulation of 2-dimensional fluidized-bed, Powder Technology 77 (1993) 79-87. 


\section{外部 発表成果}

\section{口頭・ポスター発表}

1. Higashida K., Yamada T., Tsuji T., Tanaka T., “A numerical model for the motion of large nonspherical object in fluidized bed", ASME-JSMEKSME Joint Fluids Engineering Conference 2015 (Seoul, Korea, Jul. 26-31, 2015) AJK201532744.

2. Higashida K., Rai K., Yoshimori W., Ikegai T., Tsuji T., Harada S., Oshitani J., Tanaka T., "Vertical force acting on large object floating in gas-fluidized bed (Direct comparison between numerical simulation and Lagrangian measurement)", 2015 AIChE Annual Meeting (Salt Lake City, USA, Nov. 8-13, 2015) 140c.

3. 東田 恭平, 雷 健太, 吉森 亘, 池貝 友喜, 辻拓也, 原田周作, 押谷潤, 田中敏嗣, “固 気流動層内の浮遊粗大物体に作用する鉛直 方向の力について（数值解析と Lagrangian センサーによる計測の直接比較)”, 第 21 回 流動化・粒子プロセッシングシンポジウム (Kitakyushu, Dec. 10-11, 2015).

4. 辻 拓也, 東田恭平, 田中敏嗣, “DEM-CFD カップリング法による大規模流動層解析”, 第 29 回数值流体力学シンポジウム (Fukuoka, Dec. 15-17, 2015) E04-5. 